\title{
Bacterial carbon demand and growth efficiency in a coastal upwelling system
}

\author{
Christian Lønborg ${ }^{1,2,4, *}$, Sandra Martínez-García ${ }^{3}$, Eva Teira ${ }^{3}$, \\ Xosé A. Álvarez-Salgado ${ }^{1}$
}

${ }^{1}$ CSIC, Instituto de Investigacións Mariñas, Eduardo Cabello 6, 36208 Vigo, Spain

${ }^{2}$ Scottish Association for Marine Science, Oban, Argyll PA37 1QA, UK

${ }^{3}$ Departamento de Ecoloxía e Bioloxía Animal, Universidade de Vigo, 36200 Vigo, Spain

${ }^{4}$ Present address: Swansea University, College of Biosciences, Wallace Building, Singleton Park, Swansea SA2 8PP, UK

\begin{abstract}
Eleven culture experiments were conducted in the coastal upwelling system of the Ría de Vigo (NW Iberian Peninsula) by inoculating GF/C filtrated (10\%) in $0.2 \mu \mathrm{m}$ filtrated (90\%) surface seawater collected under contrasting hydrographic conditions. Short-term (4 d) laboratory incubations were performed in the dark at $15^{\circ} \mathrm{C}$. Dissolved organic carbon (DOC) concentration, bacterial biomass (BB), bacterial production (BP) and electron transport system (ETS) activity were then monitored to: (1) study the course of bacterial carbon demand (BCD) and growth efficiency (BGE) during the incubation period; and (2) determine how BCD and BGE were linked with changing environmental conditions. Following the $4 \mathrm{~d}$ incubation, BP decreased by $<4$ times its initial values (range from 3 to 11 times) and ETS activity increased by 6 times its initial values (range from 1 to 75 times). As a result, BCD increased by 5 times (range from 1 to 16 times) and the BGE decreased by 15 times (range from 2 to 55 times) over the same period. BGE integrated over the $4 \mathrm{~d}$ incubation period ranged from $7 \pm 1 \%$ to $55 \pm 11 \%$ (mean \pm SD: $27 \pm 15 \%$ ); integrated BGE increased significantly $\left(R^{2}=0.64, p<\right.$ 0.003 ) with the initial concentration of dissolved inorganic nitrogen (DIN), and decreased significantly $\left(\mathrm{R}^{2}=0.55, \mathrm{p}<0.01\right)$ with the $\mathrm{C}: \mathrm{N}$ ratio of the bioavailable dissolved organic matter (BDOM). A multiple linear regression with DIN and the C:N ratio of BDOM explained $89 \%$ of the observed variability in the integrated BGE, demonstrating the strong dependence of growth efficiency on nutrient conditions and the quality of the organic substrate feeding the community of this coastal embayment.
\end{abstract}

KEY WORDS: Bacterial carbon demand $\cdot$ Bacterial growth efficiency $\cdot$ Inorganic nutrients $\cdot$ DOM stoichiometry $\cdot$ Coastal upwelling

\section{INTRODUCTION}

Dissolved organic carbon (DOC) constitutes the major carbon source for heterotrophic bacteria growth in marine pelagic systems (Hedges 2002). The bacterial use of DOC is therefore a central issue for understanding carbon cycling through the microbial food web (Carlson 2002, Gasol et al. 2008). After bacterial assimilation, organic carbon has 2 likely pathways: it is either transformed into new bacterial biomass (BB) or respired to $\mathrm{CO}_{2}$ by bacterial respiration (BR). The ratio between bacterial production (BP) and the sum of BP and $\mathrm{BR}$ is termed the bacterial growth efficiency (BGE), which typically ranges from 1 to $60 \%$ (del Giorgio \& Cole 1998), meaning that between 40 and $99 \%$ of the assimilated carbon is used for respiration. The approach often used to determine BGE is controlled laboratory incubations, where DOC concentration and microbial biomass are followed over time. This approach is associated with some methodological problems such as changes in bacterial community structure and physiology, and carbon and nutrient availability. 
This, together with the need for various conversion factors to convert bacterial abundance and uptake of radioactive substances into biomass, adds uncertainties to BGE estimates. In addition, the influence of short-term incubation (days) on bacterial carbon demand (BCD) and growth efficiency is still unresolved, and there are only a few seasonal studies describing how BGE changes in relation to environmental conditions (Sherry et al. 1999, Reinthaler \& Herndl 2005, Alonso-Sáez et al. 2008), which highly constrains our ability to model and predict the role of heterotrophic bacteria in the carbon cycle (Carlson et al. 1999).

The coastal ocean represents $<10 \%$ of the ocean surface, but contributes 18 to $33 \%$ of oceanic primary production and 27 to $50 \%$ of new production (Walsh 1991, Wollast 1998, Gattuso et al. 1998). Coastal upwelling systems are particularly dynamic areas, as they account for $>10 \%$ of global new production (Chavez \& Toggweiler 1995). The Galician Rías Baixas are 4 coastal Vshaped embayments in the NW Iberian Peninsula, situated at the boundary between the temperate and sub-polar regimes of the eastern North Atlantic. The high productivity of the Rías is driven by upwelling and downwelling episodes, leading to highly variable hydrographic and environmental conditions (ÁlvarezSalgado et al. 2010). Previous data on the functioning of the microbial system in coastal upwelling areas suggest that most of the organic matter produced photosynthetically is channeled through the microbial food web (Teira et al. 2003), although the links between bacterial carbon cycling and changing environmental conditions have not been examined in detail.

In this study we conducted 11 seawater cultures over an annual cycle in the highly dynamic coastal upwelling system of the Ría de Vigo (NW Iberian peninsula). This study complements previous work by Lønborg et al. (2010), where the degradation rates and $\mathrm{C}: \mathrm{N}: \mathrm{P}$ molar ratios of dissolved organic matter (DOM) in the Ría de Vigo were followed in the same incubations. The objectives of the present study were (1) to determine the time course of BCD and BGE during laboratory incubations, and (2) to find parametric relationships between those variables and the availability of organic and inorganic substrates in the incubated water.

\section{MATERIALS AND METHODS}

Study area and sampling. The Ría de Vigo is a coastal embayment on the western coast of the Iberian Peninsula. It is $33 \mathrm{~km}$ long, with a surface area of 176 $\mathrm{km}^{2}$, a volume of $3.32 \mathrm{~km}^{3}$, and an average flushing time of $7 \mathrm{~d}$. The physical and chemical environment is influenced by periodic wind-driven upwelling and downwelling events (Álvarez-Salgado et al. 2010). The sampling site was located at $42^{\circ} 14.5^{\prime} \mathrm{N}$ and $8^{\circ} 45.8^{\prime} \mathrm{W}$, in the middle sector of the embayment, a position appropriate for evaluating the main processes occurring in the outer Ría de Vigo (Nogueira et al. 1997).

Water samples were collected during autumn (20 and 27 September, and 4 October 2007), winter (31 January, and 7 and 14 February 2008), spring (17 and 24 April 2008) and summer (26 June, and 3 and 7 July 2008). Samples were taken at $5 \mathrm{~m}$ depth using a $25 \mathrm{l}$ Niskin bottle. Salinity and temperature were measured prior to sampling with an SBE 9/11 CTD probe. Samples for chlorophyll a ( $\mathrm{chl}$ a) were collected by filtering 100 to $200 \mathrm{ml}$ of seawater through a GF/F filter ( $\sim 0.7 \mu \mathrm{m}$ pore size), and analyzing them after $90 \%$ acetone extraction with a Turner Designs 10000R fluorometer (Yentsch \& Menzel 1963).

Dilution culture setup. Filtration of the seawater started within $10 \mathrm{~min}$ of collection. One part was filtered through pre-combusted $\left(450^{\circ} \mathrm{C}\right.$ for $\left.4 \mathrm{~h}\right) \mathrm{GF} / \mathrm{C}$ filters $(\sim 1.2 \mu \mathrm{m}$ pore size) to establish a microbial culture and the second part was gravity-filtered through a dual-stage $(0.8$ and $0.2 \mu \mathrm{m})$ filter cartridge (PallAcroPak with Supor membrane), which had been prewashed with 101 of Milli-Q. The filtrates were thereafter kept in the dark until arrival in the laboratory, where seawater cultures were prepared by diluting the GF/C filtrate in a 201 carboy at a 1:9 ratio with the $0.2 \mu \mathrm{m}$ seawater filtrate.

The water was transferred into $500 \mathrm{ml}$ glass bottles and incubated in the dark at a constant temperature of $15^{\circ} \mathrm{C}$, with 4 replicate bottles used for subsampling at incubation times $0,1,2$, and $4 \mathrm{~d}$. Unfiltered water from these bottles was used to follow changes in electron transport system (ETS) activity and bacterial abundance (BA). BA and ETS activity in Expts 1, 2, 3 and 11 was measured on incubation Day 5 instead of Day 4. For simplicity we refer to all samples as Day 4 throughout the text. Samples for analysis of dissolved inorganic nitrogen (DIN: $\mathrm{NH}_{4}{ }^{+}+\mathrm{NO}_{2}^{-}+\mathrm{NO}_{3}{ }^{-}$) and phosphorus (DIP: $\mathrm{HPO}_{4}{ }^{2-}$ ), DOC, total dissolved nitrogen (TDN) and total dissolved phosphorus (TDP) were collected in 4 replicates on Day 0 and Day 4. All samples for the dissolved phase were collected after filtration through $0.2 \mu \mathrm{m}$ filters. Glassware was acid-washed in $10 \% \mathrm{HCl}$ and rinsed with Milli-Q and sample water prior to use.

Sample analysis. BP was measured by $\left[{ }^{3} \mathrm{H}\right]$ thymidine incorporation (Fuhrman \& Azam 1980). Four replicate $9.9 \mathrm{ml}$ samples and 2 trichloroacetic-acidkilled samples were spiked with an aqueous stock solution of [ ${ }^{3} \mathrm{H}$-methyl] thymidine (40 nmol final concentration). The samples were incubated in the dark at $15^{\circ} \mathrm{C}$ for $2 \mathrm{~h} ; 10 \mathrm{ml}$ of ice-cold trichloracetate (TCA) 
was thereafter added and samples were filtered onto $0.2 \mu \mathrm{m}$ polycarbonate filters (presoaked in thymidine), and washed with $95 \%$ ethanol and autoclaved Milli-Q water. The filters were then dried at room temperature $(24 \mathrm{~h})$ and mixed with $10 \mathrm{ml}$ of scintillation fluid (Sigma-Fluor). The radioactivity incorporated into cells was measured using a spectral liquid scintillation counter. Thymidine incorporated into bacterial biomass was converted to carbon production using the theoretical conversion factors of $2 \times 10^{18} \mathrm{cells} \mathrm{mol}^{-1}$ thymidine (Fuhrman \& Azam 1980) and $30 \mathrm{fg} \mathrm{C} \mathrm{cell}^{-1}$, the latter being characteristic of coastal bacterial assemblages (Fukuda et al. 1998).

Samples for determining BA were fixed (1 to $2 \mathrm{~h}$ ) with formol in the dark, filtered onto $0.2 \mu \mathrm{m}$ polycarbonate filters, and stored at $-20^{\circ} \mathrm{C}$ until counted. The samples were stained with a 4',6-diamidino-2phenylindole (DAPI) mix before being counted on a Leica DMBL microscope equipped with a $100 \mathrm{~W} \mathrm{Hg}$ lamp and appropriate filters. More than 800 DAPIstained cells were counted per sample. BB was calculated from BA, using the same cell-to-carbon conversion factor as for BP.

Samples for determining DIN and DIP were collected in $50 \mathrm{ml}$ acid-washed polyethylene bottles and kept frozen $\left(-20^{\circ} \mathrm{C}\right)$ until analysis using standard colorimetric methods with an Alpkem segmented flow analyser.

DOC and TDN were measured using a Shimadzu total organic carbon (TOC) analyser (Pt catalyst) connected to an Antek total nitrogen (TN) measuring unit. Three to 5 replicate injections of $150 \mu \mathrm{l}$ were prepared per sample. Concentrations were determined by subtracting a Milli-Q blank and dividing by the slope of a daily standard curve of potassium hydrogen phthalate and glycine. Using the deep ocean reference (Sargasso Sea deep water, $2600 \mathrm{~m}$ ), we obtained a concentration of $46.0 \pm 2.0 \mu \mathrm{M}$ (mean $\pm \mathrm{SD}$ ) for DOC and $22.0 \pm 2.0 \mu \mathrm{M}$ for TDN. Dissolved organic nitrogen (DON) concentrations were calculated as the difference between TDN and DIN. The concentration of TDP was determined by wet-oxidizing in acid persulphate $\left(120^{\circ} \mathrm{C}, 75 \mathrm{~min}\right)$ and measuring the liberated orthophosphate using segment flow analysis calibrated with a daily calibration curve (Hansen \& Koroleff 1999). Dissolved organic phosphorus (DOP) concentrations were calculated as the difference between TDP and DIP.

ETS activity was measured using the reduction of 2(4-iodophenyl)-3-(4-nitrophenyl)-5-phenyl tetrazolium chloride (INT) to insoluble formazan crystals (INTF), as described by Martínez-García et al. (2009). This method has been shown to provide real, non-potential respiration rates. The activity was measured using a final concentration of $0.2 \mathrm{mM}$ INT and $1 \mathrm{~h}$ incubations of 3 replicate samples $(10 \mathrm{ml})$, with 1 formol-killed control. The incubations were terminated by adding for$\mathrm{mol}$ and filtering onto $0.2 \mu \mathrm{m}$ polycarbonate filters. The filters were then stored at $-20^{\circ} \mathrm{C}$ until further processing. The respiration rates derived from ETS activity $\left(R_{\mathrm{ETS}}\right.$, in $\left.\mu \mathrm{MO}_{2} \mathrm{~h}^{-1}\right)$ were obtained by multiplying the in vivo ETS activity (in $\mu \mathrm{M}$ INTF) by the empirically derived conversion factor of 12.8 , which has previously been shown to be applicable to incubation studies (Martínez-García et al. 2009).

The microbial respiratory quotient $(\mathrm{RQ})$, defined as the ratio of $\mathrm{mol} \mathrm{CO}_{2}$ production per $\mathrm{mol} \mathrm{O}_{2}$ used, can fluctuate considerably, depending on the characteristics of the substrates being degraded. We used the average $R Q$ values (range 1.35 to 1.53 ) calculated by Lønborg et al. (2010) from the C:N:P composition of bioavailable DOM (BDOM) for the same experiments.

The BCD at Day 0 and Day 4 of the incubation period was calculated as the sum of BP and ETS activity:

$$
\mathrm{BCD}=\mathrm{BP}+\mathrm{ETS}
$$

The BGE at Day 0 and Day 4 of the incubation period was calculated as BP divided by the sum of BP and ETS activity:

$$
\mathrm{BGE}=\mathrm{BP} /(\mathrm{BP}+\mathrm{ETS})
$$

The integrated BCD over the $4 \mathrm{~d}$ incubation period was calculated as the DOC consumed $(\triangle \mathrm{DOC})$ :

$$
\mathrm{BCD}=\Delta \mathrm{DOC} / \Delta t
$$

The integrated BGE over the $4 \mathrm{~d}$ incubation period was calculated as the net growth in BB between Day 0 and Day 4 (BG) divided by $\triangle \mathrm{DOC}$ :

$$
\mathrm{BGE}=\mathrm{BG} / \triangle \mathrm{DOC}
$$

Regression analyses were performed using the best fit between the 2 variables $X$ and $Y$ obtained by regression model II as described in Sokal \& Rohlf (1995). In cases where the intercept was not significantly different from zero, it was set to zero and a new slope was calculated. Prior to performing regression analysis, normality was checked, and the confidence level was set at $95 \%$. All statistical analyses were performed using Statistica 6.0.

\section{RESULTS}

\section{Environmental conditions}

Environmental conditions during the sampling period in the Ría de Vigo have previously been described in detail by Lønborg et al. (2010). Briefly, during the autumn sampling, conditions evolved from upwelling to moderate downwelling. Favourable 
winds resulted in a decrease in water temperature from $>16^{\circ} \mathrm{C}$ to $<14^{\circ} \mathrm{C}$, increasing DIN concentration from 3 to $13 \mu \mathrm{M}$ and DIP from 0.19 to $0.68 \mu \mathrm{M}$ (Table 1). $\mathrm{Chl}$ a concentrations remained constant at $\sim 3 \mathrm{mg} \mathrm{m}^{-3}$. The winter sampling period started with relaxation evolving into strong downwelling conditions. Water temperature was relatively constant at $\sim 13^{\circ} \mathrm{C}_{i}$ DIN and DIP concentrations were $>8$ and $>0.42 \mu \mathrm{M}$, respectively (Table 1 ; chl a levels were $<1.5 \mathrm{mg} \mathrm{m}^{-3}$ ). The spring sampling period was dominated by moderate downwelling winds, with temperatures varying between 14 and $15^{\circ} \mathrm{C}$, DIN levels $>5 \mu \mathrm{M}$, DIP constant at $0.09 \mu \mathrm{M}$ and chl a concentrations ranging from 3.0 to $8.4 \mathrm{~g} \mathrm{~m}^{-3}$. In the summer sampling period, initial strong upwelling was followed by moderate downwelling conditions. The water temperatures reached $>17^{\circ} \mathrm{C}$, while DIN levels were $<3 \mu \mathrm{M}$, DIP varied between 0.02 and $0.38 \mu \mathrm{M}$ and chl $a$ concentrations varied between
1.1 and $4.5 \mathrm{mg} \mathrm{m}^{-3}$ (Table 1; see also Figs. $2 \& 3$ of Lønborg et al. 2010).

\section{Inorganic nutrients and DOC utilization}

In all cultures, the DIN and DIP concentrations were over the detection limit $( \pm 0.1 \mu \mathrm{M}$ and $\pm 0.02 \mu \mathrm{M}$, respectively) during the $4 \mathrm{~d}$ incubation period. Initial DOC varied from 73 to $94 \mu \mathrm{M}$, DON from 4.5 to $7.2 \mu \mathrm{M}$ and DOP from 0.12 to $0.32 \mu \mathrm{M}$ (Table 1). Bacterial DOM degradation over $4 \mathrm{~d}$ resulted in the removal of 11,28 and $44 \%$ of the initial DOC, DON and DOP pools, respectively, corresponding to 57,73 and $78 \%$ of the total bioavailable DOC, DON and DOP (BDOC, BDON, BDOP) quantified by Lønborg et al. (2010) in long-term incubations (50 to $70 \mathrm{~d}$ ) of the same sample water (Table 1).

Table 1. Initial concentrations of dissolved organic carbon $\left(\mathrm{DOC}_{0}\right)$, change after $4 \mathrm{~d}(\triangle \mathrm{DOC})$, total bioavailable DOC (BDOC); initial concentrations of dissolved organic nitrogen $\left(\mathrm{DON}_{0}\right)$, total bioavailable DON (BDON); initial concentrations of dissolved organic phosphorus $\left(\mathrm{DOP}_{0}\right.$ ), total bioavailable DOP (BDOP) (Lønborg et al. 2010). Initial concentrations of dissolved inorganic phosphate (DIP), nitrate $\left(\mathrm{NO}_{3}^{-}\right)$, nitrite $\left(\mathrm{NO}_{2}^{-}\right)$, and ammonium $\left(\mathrm{NH}_{4}{ }^{+}\right)$. Values are means of 4 replicates $\pm \mathrm{SD}$. nd $=$ not determined

\begin{tabular}{|c|c|c|c|c|c|c|c|c|c|c|c|}
\hline $\begin{array}{l}\text { Date } \\
\text { (d-mo-yr) }\end{array}$ & $\begin{array}{c}\mathrm{DOC}_{0} \\
\left.(\mu \mathrm{M})^{2}\right)\end{array}$ & $\begin{array}{l}\Delta \mathrm{DOC} \\
(\mu \mathrm{M} \mathrm{C})\end{array}$ & $\begin{array}{l}\text { BDOC } \\
(\mu \mathrm{M} \mathrm{C})\end{array}$ & $\begin{array}{c}\mathrm{DON}_{0} \\
(\mu \mathrm{M} N)\end{array}$ & $\begin{array}{l}\text { BDON } \\
(\mu M N)\end{array}$ & $\begin{array}{c}\mathrm{DOP}_{0} \\
(\mu \mathrm{M})\end{array}$ & $\begin{array}{l}\text { BDOP } \\
(\mu \mathrm{M})\end{array}$ & $\begin{array}{c}\text { DIP } \\
(\mu \mathrm{M} P)\end{array}$ & $\begin{array}{c}\mathrm{NO}_{3}^{-} \\
(\mu \mathrm{M})\end{array}$ & $\begin{array}{c}\mathrm{NO}_{2}^{-} \\
(\mu \mathrm{M} \mathrm{N})\end{array}$ & $\begin{array}{c}\mathrm{NH}_{4}^{+} \\
(\mu \mathrm{M} \mathrm{N})\end{array}$ \\
\hline & \pm 1 & \pm 2 & \pm 3 & .7 & .7 & 2 & 8 & 0.19 & 0.14 & 01 & 2.83 \\
\hline 07 & \pm 1 & $9 \pm 3$ & \pm 1 & \pm 0.4 & \pm 1.2 & 03 & .06 & $0.68 \pm$ & $5.25 \pm$ & 01 & .02 \\
\hline & \pm 2 & $5 \pm 2$ & $12 \pm 2$ & 5.5 & 1.0 & 04 & 07 & $0.54=$ & 9.24 & 01 & 2.84 \\
\hline 31-01 & $75 \pm 1$ & $3 \pm 2$ & $9 \pm 1$ & $5.2 \pm 0.3$ & $1.7 \pm 0.6$ & $0.19 \pm 0.01$ & $0.11 \pm 0.04$ & $0.46 \pm 0.01$ & $7.03 \pm 0.02$ & $0.38=$ & $2.19 \pm 0.09$ \\
\hline & $77 \pm 1$ & $2 \pm 1$ & \pm 1 & $5.4 \pm 0.6$ & $1.7 \pm 1.5$ & $0.22 \pm 0.02$ & & $0.56 \pm$ & & & $3.18=$ \\
\hline & & $6 \pm 2$ & $10 \pm 2$ & & & 0.12 & 0. & 0.42 & & & 11 \\
\hline 17 & \pm 1 & $7 \pm 2$ & $13 \pm 1$ & 5.7 & $2.2 \pm 1.4$ & $0.19 \pm 0.04$ & $0.14 \pm 0.07$ & 0.09 & 0.0 & 0.0 & 0.31 \\
\hline $24-04-2008$ & $85 \pm 1$ & $7 \pm 1$ & $11 \pm 1$ & $6.1 \pm 0.2$ & $2.5 \pm 0.7$ & nd & nd & $0.09 \pm 0.01$ & $3.86 \pm 0.07$ & $0.12 \pm 0.01$ & $1.27 \pm 0.13$ \\
\hline $26-06-2008$ & $88 \pm 1$ & $13 \pm 2$ & $17 \pm 2$ & $6.1 \pm 0.5$ & $2.5 \pm 0.9$ & $0.16 \pm 0.03$ & $0.10 \pm 0.08$ & $0.27 \pm 0.01$ & $0.26 \pm 0.01$ & $0.07 \pm 0.01$ & $0.38 \pm 0.29$ \\
\hline & $2 \pm 1$ & $9 \pm 1$ & $14 \pm 1$ & & $2.0 \pm 1.2$ & $0.20 \pm 0.03$ & $0.11 \pm 0.06$ & $0.02 \pm 0.01$ & $0.02 \pm 0.01$ & $0.02 \pm 0.01$ & $1.17 \pm 0.16$ \\
\hline & \pm 2 & $13 \pm 1$ & $20 \pm 1$ & & $2.9 \pm 0.7$ & $0.23 \pm 0.03$ & $0.17 \pm 0.04$ & $0.38 \pm 0.01$ & $0.64 \pm$ & $0.10 \pm$ & $2.35=$ \\
\hline Mean $\pm \mathrm{SD}$ & $82 \pm 7$ & $9 \pm 7$ & $14 \pm 6$ & $5.7 \pm 0.7$ & $2.2 \pm 0.6$ & $0.20 \pm 0.05$ & $0.13 \pm 0.05$ & $0.34 \pm 0.22$ & $3.55 \pm 3.45$ & $0.26 \pm 0.21$ & $2.12 \pm 1.28$ \\
\hline
\end{tabular}

Table 2. Initial $\left(\mathrm{BP}_{0}, \mathrm{BA}_{0}, \mathrm{BB}_{0}\right)$ and final $\left(\mathrm{BP}_{4}, \mathrm{BA}_{4}, \mathrm{BB}_{4}\right)$ bacterial production (BP), abundance (BA) and biomass (BB), growth in bacterial biomass $(\mathrm{BG})$ and $\mu$ at Day $0\left(\mathrm{BP}_{0} / \mathrm{BB}_{0}\right)$ and Day $4\left(\mathrm{BP}_{4} / \mathrm{BB}_{4}\right)$ of the incubations. Values are means of 4 replicates $\pm \mathrm{SD}$

\begin{tabular}{|c|c|c|c|c|c|c|c|c|c|}
\hline $\begin{array}{l}\text { Date } \\
\text { (d-mo-yr) }\end{array}$ & $\begin{array}{c}\mathrm{BP}_{0} \\
\left(\mu \mathrm{C} \mathrm{C}^{-1}\right)\end{array}$ & $\begin{array}{c}\mathrm{BP}_{4} \\
\left(\mu \mathrm{M} \mathrm{C}^{-1}\right)\end{array}$ & $\begin{array}{l}\mathrm{BA}_{0}\left(\times 10^{5}\right. \\
\left.\text { cells ml } \mathrm{ml}^{-1}\right)\end{array}$ & $\begin{array}{l}\mathrm{BA}_{4}\left(\times 10^{5}\right. \\
\left.\text { cells ml }{ }^{-1}\right)\end{array}$ & $\begin{array}{c}\mathrm{BB}_{0} \\
(\mu \mathrm{M} \mathrm{C})\end{array}$ & $\begin{array}{c}\mathrm{BB}_{4} \\
(\mu \mathrm{M} \mathrm{C})\end{array}$ & $\begin{array}{c}B G \\
(\mu \mathrm{M} \mathrm{C})\end{array}$ & $\begin{array}{c}\mathrm{BP}_{0} / \mathrm{BB}_{0} \\
\left(\mathrm{~d}^{-1}\right)\end{array}$ & $\begin{array}{c}\mathrm{BP}_{4} / \mathrm{BB}_{4} \\
\left(\mathrm{~d}^{-1}\right)\end{array}$ \\
\hline 20-09-2007 & $0.16 \pm 0.02$ & $0.05 \pm 0.01$ & $2.5 \pm 0.2$ & $11.4 \pm 0.2$ & $0.63 \pm 0.05$ & $2.84 \pm 0.05$ & $2.21 \pm 0.10$ & $7.8 \pm 1.4$ & $0.6 \pm 0.1$ \\
\hline $27-09-2007$ & $0.06 \pm 0.02$ & $0.03 \pm 0.01$ & $2.6 \pm 0.1$ & $11.3 \pm 0.5$ & $0.64 \pm 0.02$ & $2.81 \pm 0.12$ & $2.17 \pm 0.13$ & $3.0 \pm 0.9$ & $0.4 \pm 0.1$ \\
\hline 04-10-2007 & $0.06 \pm 0.02$ & $0.05 \pm 0.01$ & $3.1 \pm 0.1$ & $11.4 \pm 0.5$ & $0.78 \pm 0.02$ & $2.84 \pm 0.12$ & $2.06 \pm 0.13$ & $2.3 \pm 0.7$ & $0.5 \pm 0.1$ \\
\hline 31-01-2008 & $0.08 \pm 0.01$ & $0.05 \pm 0.01$ & $1.5 \pm 0.1$ & $6.9 \pm 0.3$ & $0.38 \pm 0.01$ & $1.71 \pm 0.08$ & $1.34 \pm 0.09$ & $6.2 \pm 0.8$ & $0.9 \pm 0.2$ \\
\hline 07-02-2008 & $0.02 \pm 0.01$ & $0.01 \pm 0.01$ & $1.7 \pm 0.1$ & $8.9 \pm 0.5$ & $0.43 \pm 0.02$ & $2.23 \pm 0.12$ & $1.80 \pm 0.14$ & $1.5 \pm 0.7$ & $0.2 \pm 0.1$ \\
\hline $14-02-2008$ & $0.06 \pm 0.01$ & $0.02 \pm 0.01$ & $1.3 \pm 0.1$ & $7.6 \pm 0.4$ & $0.33 \pm 0.01$ & $1.89 \pm 0.09$ & $1.56 \pm 0.11$ & $5.6 \pm 1.0$ & $0.3 \pm 0.1$ \\
\hline $17-04-2008$ & $0.05 \pm 0.01$ & $0.03 \pm 0.01$ & $6.1 \pm 0.3$ & $9.9 \pm 0.3$ & $1.53 \pm 0.07$ & $2.48 \pm 0.07$ & $0.95 \pm 0.14$ & $1.1 \pm 0.2$ & $0.3 \pm 0.1$ \\
\hline 24-04-2008 & $0.06 \pm 0.01$ & $0.04 \pm 0.01$ & $2.3 \pm 0.1$ & $9.3 \pm 0.6$ & $0.57 \pm 0.03$ & $2.32 \pm 0.16$ & $1.75 \pm 0.19$ & $3.3 \pm 0.6$ & $0.5 \pm 0.1$ \\
\hline 26-06-2008 & $0.08 \pm 0.01$ & $0.05 \pm 0.01$ & $4.3 \pm 0.4$ & $10.9 \pm 0.3$ & $1.07 \pm 0.09$ & $2.72 \pm 0.09$ & $1.64 \pm 0.18$ & $2.3 \pm 0.4$ & $0.6 \pm 0.1$ \\
\hline 03-07-2008 & $0.09 \pm 0.01$ & $0.03 \pm 0.01$ & $1.8 \pm 0.8$ & $9.3 \pm 0.4$ & $0.44 \pm 0.03$ & $2.33 \pm 0.16$ & $1.89 \pm 0.19$ & $6.3 \pm 1.0$ & $0.4 \pm 0.1$ \\
\hline $10-07-2008$ & $0.11 \pm 0.01$ & $0.05 \pm 0.01$ & $2.3 \pm 0.6$ & $22.7 \pm 0.9$ & $0.56 \pm 0.02$ & $5.67 \pm 0.12$ & $5.10 \pm 0.14$ & $5.7 \pm 0.7$ & $0.3 \pm 0.1$ \\
\hline Mean \pm SD & $0.08 \pm 0.04$ & $0.04 \pm 0.01$ & $2.7 \pm 1.4$ & $10.9 \pm 4.2$ & $0.67 \pm 0.35$ & $2.71 \pm 1.05$ & $2.04 \pm 1.08$ & $4.1 \pm 2.3$ & $0.5 \pm 0.2$ \\
\hline
\end{tabular}




\section{Bacterial abundance and production}

BA increased in all cultures (Fig. 1) following the decreases in DOM (Table 1). Initial BA varied from 1.3 to $6.1 \times 10^{5}$ cells ml $^{-1}$, reaching 6.9 to $22.7 \times 10^{5}$ cells $\mathrm{ml}^{-1}$ after $4 \mathrm{~d}$ of incubation (Table 2), corresponding to a BG ranging from $0.95 \pm 0.14$ to $5.10 \pm 0.14 \mu \mathrm{M} \mathrm{C}$ (Table 2). The BA samples for Days 2 and 3 of 2 summer experiments ( 3 and 7 July 2008) were unfortunately lost. As found by Teira et al. (2009) for the same experiments, the bacterial growth rates varied between 0.5 to $0.8 \mathrm{~d}^{-1}$, resulting in an average turnover
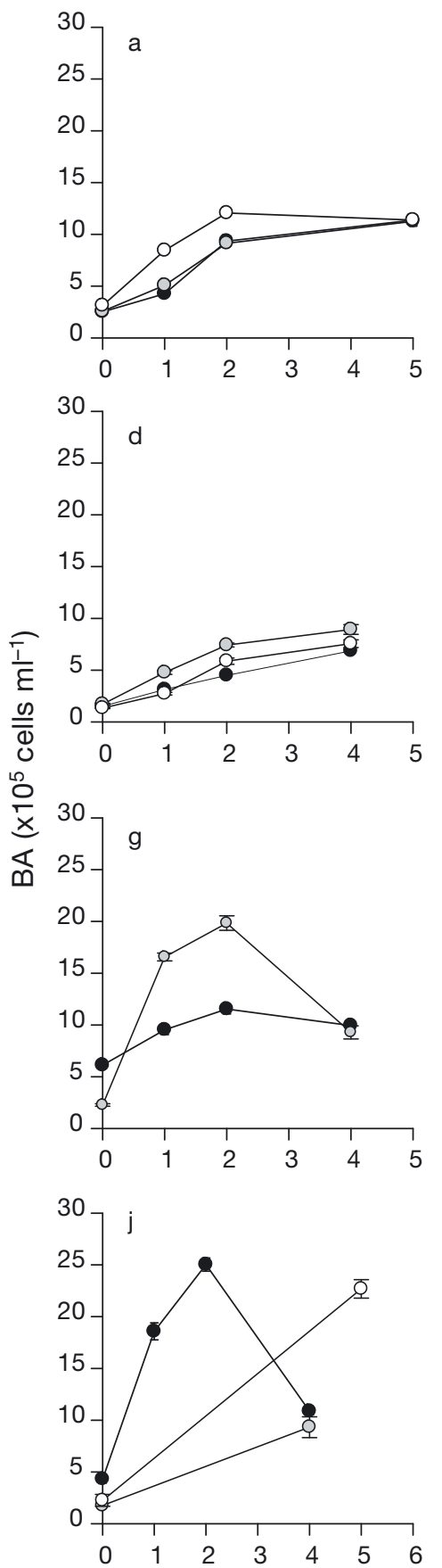
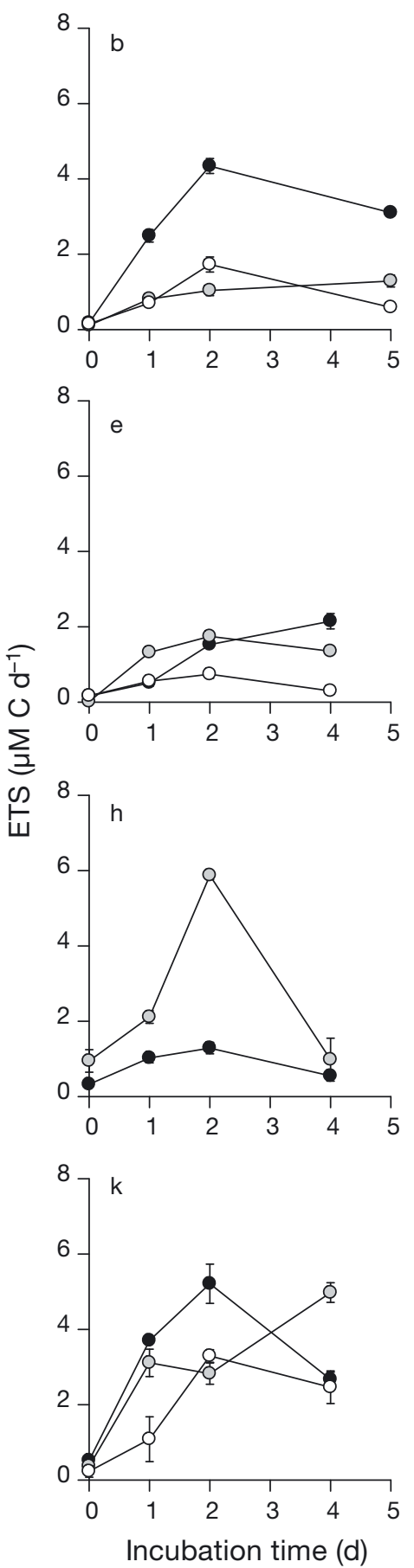
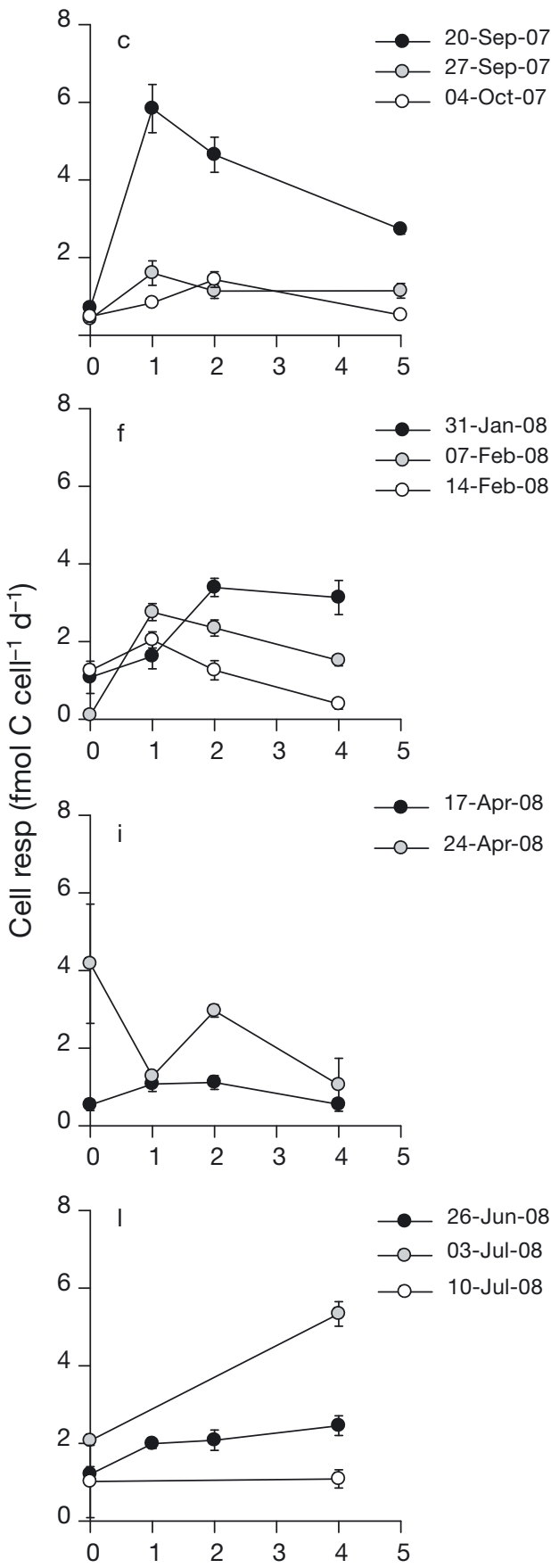

Fig. 1. Time evolution of bacterial abundance (BA; $a, d, g, j)$, electron transport system (ETS) activity (b,e,h,k) and cell-specific respiration (Cell resp; $\mathrm{C}, \mathrm{f}, \mathrm{i}, \mathrm{l})$ during the incubations. Error bars represent $\mathrm{SD}$ 
time of 29 h. No clear relationship was noted between the obtained growth rates and environmental variables (Teira et al. 2009).

Initial BP ranged from $0.02 \pm 0.01$ to $0.16 \pm 0.02 \mu \mathrm{M} \mathrm{C}$ $\mathrm{d}^{-1}$, with higher values during autumn and summer (Table 2). The BP decreased in all experiments, reaching values between $0.01 \pm 0.01$ and $0.05 \pm 0.01 \mu \mathrm{M} \mathrm{C}$ $\mathrm{d}^{-1}$ after $4 \mathrm{~d}$ of incubation (Table 2). The specific growth rate $(\mu)$ varied initially between $1.1 \pm 0.2$ to $7.8 \pm 1.4 \mathrm{~d}^{-1}$, declining to between $0.2 \pm 0.1$ and $0.9 \pm$ $0.2 \mathrm{~d}^{-1}$ on incubation Day 4 (Table 2 ).

\section{ETS activity}

The respiratory ETS activity varied initially between $0.02 \pm 0.01$ and $0.95 \pm 0.30 \mu \mathrm{M} \mathrm{C} \mathrm{d}^{-1}$, increasing to between $0.30 \pm 0.09$ and $4.98 \pm 0.26 \mu \mathrm{M} \mathrm{C} \mathrm{d}^{-1}$ at incubation Day 4 (Fig. 1). Calculating the cell-specific ETS activity, an initial range from $0.11 \pm 0.06$ to $4.18 \pm$ $1.53 \mathrm{fmol} \mathrm{C}$ cell $^{-1} \mathrm{~d}^{-1}$ was found, reaching values between $0.83 \pm 0.08$ and $5.84 \pm 0.62 \mathrm{fmol} \mathrm{C}$ cell $^{-1} \mathrm{~d}^{-1}$ after 1 to $2 \mathrm{~d}$ of incubation and values between $0.39 \pm 0.13$ and $5.34 \pm 0.54 \mathrm{fmol} \mathrm{C} \mathrm{cell}^{-1} \mathrm{~d}^{-1}$ at Day 4 (Fig. 1).

\section{Bacterial carbon demand and growth efficiency}

The BCD varied initially between $0.1 \pm 0.1$ and $1.0 \pm$ $0.3 \mu \mathrm{M} \mathrm{C} \mathrm{d}^{-1}$ (mean \pm SD: $0.4 \pm 0.3 \mu \mathrm{M} \mathrm{C} \mathrm{d}^{-1}$ ), increasing to between $0.3 \pm 0.1$ and $5.0 \pm 0.3 \mu \mathrm{M} \mathrm{C} \mathrm{d}^{-1}(1.9 \pm$ $1.7 \mu \mathrm{M} \mathrm{C} \mathrm{d}^{-1}$ ) after $4 \mathrm{~d}$ of incubation (Table $3 \mathrm{a}$ ). Integrated $\mathrm{BCD}$ was highest in fall and summer, reaching values of between $0.9 \pm 0.3$ and $6.6 \pm 0.4 \mu \mathrm{M} \mathrm{C} \mathrm{d}^{-1}$ $\left(4.5 \pm 2.9 \mu \mathrm{M} \mathrm{C} \mathrm{d}^{-1}\right)$ (Table 3a).

The instantaneous BGE showed an initial average of $29 \pm 15 \%$ (range 6 to $55 \%$ ), declining to $3 \pm 2 \%$ (range 1 to $8 \%$ ) after $4 \mathrm{~d}$ of incubation (Table $3 \mathrm{~b}$ ). The integrated BGE averaged $27 \pm 15 \%$, reaching values between $8 \pm$ 1 and $55 \pm 11 \%$ (Table $3 \mathrm{~b}$ ). The availability of inorganic nutrients and the quality of the bioavailable DOM pool played an important role in determining the integrated BGE, as it was positively correlated with the initial DIN $\left(\mathrm{R}^{2}=0.67, \mathrm{p}<0.003\right.$; Fig. 2a) and negatively correlated with the C:N molar ratio of BDOM $\left(\mathrm{R}^{2}=0.55, \mathrm{p}<0.01\right.$; Fig. 2b). Furthermore, the multiple linear regression with DIN and the C:N ratio of BDOM explained $89 \%$ of the observed variability in the integrated BGE $\left(\mathrm{R}^{2}=\right.$ 0.89, p $<0.001$; Fig. 2c)

\section{DISCUSSION}

Variations in the environmental conditions of the Ría de Vigo have previously been shown to affect biogeo-
Table 3. (a) Bacterial carbon demand (BCD) and (b) growth efficiency (BGE) at incubation Day $0\left(\mathrm{BCD}_{0}, \mathrm{BGE}_{0}\right)$ and Day 4 $\left(\mathrm{BCD}_{4}, \mathrm{BGE}_{4}\right)$, and $4 \mathrm{~d}$ integrated values $\left(\mathrm{BCD}_{\text {Int }} \mathrm{BGE}_{\text {Int }}\right)$. Values are means of 4 replicates $\pm \mathrm{SE}$

\begin{tabular}{|c|c|c|c|}
\hline $\begin{array}{l}\text { Date } \\
\text { (d-mo-yr) }\end{array}$ & $\begin{array}{c}\mathrm{BCD}_{0} \\
\left(\mu \mathrm{M} \mathrm{C} \mathrm{d}^{-1}\right)\end{array}$ & $\begin{array}{c}\mathrm{BCD}_{4} \\
\left(\mu \mathrm{M} \mathrm{C} \mathrm{d}^{-1}\right)\end{array}$ & $\begin{array}{c}\mathrm{BCD}_{\text {Int }} \\
\left(\mu \mathrm{MC} \mathrm{d}^{-1}\right)\end{array}$ \\
\hline \multicolumn{4}{|l|}{ (a) } \\
\hline $20-09-2007$ & $0.3 \pm 0.1$ & $3.2 \pm 0.1$ & $6.6 \pm 0.4$ \\
\hline $27-09-2007$ & $0.2 \pm 0.1$ & $1.3 \pm 0.2$ & $2.3 \pm 0.6$ \\
\hline $04-10-2007$ & $0.2 \pm 0.1$ & $0.6 \pm 0.1$ & $1.3 \pm 0.5$ \\
\hline $31-01-2008$ & $0.2 \pm 0.1$ & $2.2 \pm 0.2$ & $0.9 \pm 0.3$ \\
\hline $07-02-2008$ & $0.1 \pm 0.1$ & $1.4 \pm 0.1$ & $1.1 \pm 0.2$ \\
\hline $14-02-2008$ & $0.2 \pm 0.1$ & $0.3 \pm 0.1$ & $1.7 \pm 0.4$ \\
\hline $17-04-2008$ & $0.4 \pm 0.1$ & $0.6 \pm 0.1$ & $1.2 \pm 0.6$ \\
\hline $24-04-2008$ & $1.0 \pm 0.3$ & $1.0 \pm 0.6$ & $1.7 \pm 0.4$ \\
\hline $26-06-2008$ & $0.6 \pm 0.1$ & $2.7 \pm 0.2$ & $2.3 \pm 0.5$ \\
\hline $03-07-2008$ & $0.5 \pm 0.2$ & $5.0 \pm 0.3$ & $2.2 \pm 0.2$ \\
\hline $10-07-2008$ & $0.3 \pm 0.2$ & $2.5 \pm 0.4$ & $2.3 \pm 0.4$ \\
\hline Mean \pm SD & $0.4 \pm 0.3$ & $1.9 \pm 1.7$ & $4.5 \pm 2.9$ \\
\hline $\begin{array}{l}\text { Date } \\
\text { (d-mo-yr) }\end{array}$ & $\begin{array}{c}\mathrm{BGE}_{0} \\
(\%)\end{array}$ & $\begin{array}{c}\mathrm{BGE}_{4} \\
(\%)\end{array}$ & $\begin{array}{c}\mathrm{BGE}_{\text {Int }} \\
(\%)\end{array}$ \\
\hline \multicolumn{4}{|l|}{ (b) } \\
\hline $20-09-2007$ & $48 \pm 11$ & $2 \pm 1$ & $8 \pm 1$ \\
\hline $27-09-2007$ & $38 \pm 18$ & $3 \pm 1$ & $23 \pm 7$ \\
\hline $04-10-2007$ & $28 \pm 16$ & $8 \pm 2$ & $40 \pm 23$ \\
\hline $31-01-2008$ & $32 \pm 12$ & $2 \pm 1$ & $36 \pm 14$ \\
\hline $07-02-2008$ & $55 \pm 45$ & $1 \pm 1$ & $41 \pm 19$ \\
\hline $14-02-2008$ & $27 \pm 6$ & $6 \pm 4$ & $23 \pm 7$ \\
\hline $17-04-2008$ & $14 \pm 5$ & $5 \pm 2$ & $19 \pm 12$ \\
\hline $24-04-2008$ & $6 \pm 3$ & $4 \pm 3$ & $26 \pm 8$ \\
\hline 26-06-2008 & $14 \pm 2$ & $2 \pm 1$ & $18 \pm 6$ \\
\hline $03-07-2008$ & $20 \pm 10$ & $1 \pm 1$ & $7 \pm 1$ \\
\hline $10-07-2008$ & $32 \pm 18$ & $2 \pm 1$ & $55 \pm 11$ \\
\hline Mean \pm SD & $29 \pm 15$ & $3 \pm 2$ & $27 \pm 15$ \\
\hline
\end{tabular}

chemical cycling and plankton community composition (e.g. Tilstone et al. 1999, Álvarez-Salgado et al. 2001, Cermeño et al. 2006, Alonso-Gutiérrez et al. 2009). The microbial parameters measured in this study showed variations that were related to environmental conditions, such as inorganic nutrient conditions and quality of the BDOM (Fig. 2).

\section{Bacterial metabolism changes during incubation}

During the course of the incubations, $\mathrm{BA}, \mathrm{BCD}$, and ETS activity increased between 1 and 75 times, while BP and BGE decreased between 1 and 55 times. Based on the BA, ETS activity and BP, we calculated the $\mu$ and cell-specific respiration rates. In calculating these rates, we were aware of the uncertainty associated with the presence of nonliving cells, which could have caused an underestimation of the rates. However, Teira et al. (2009) observed that after 

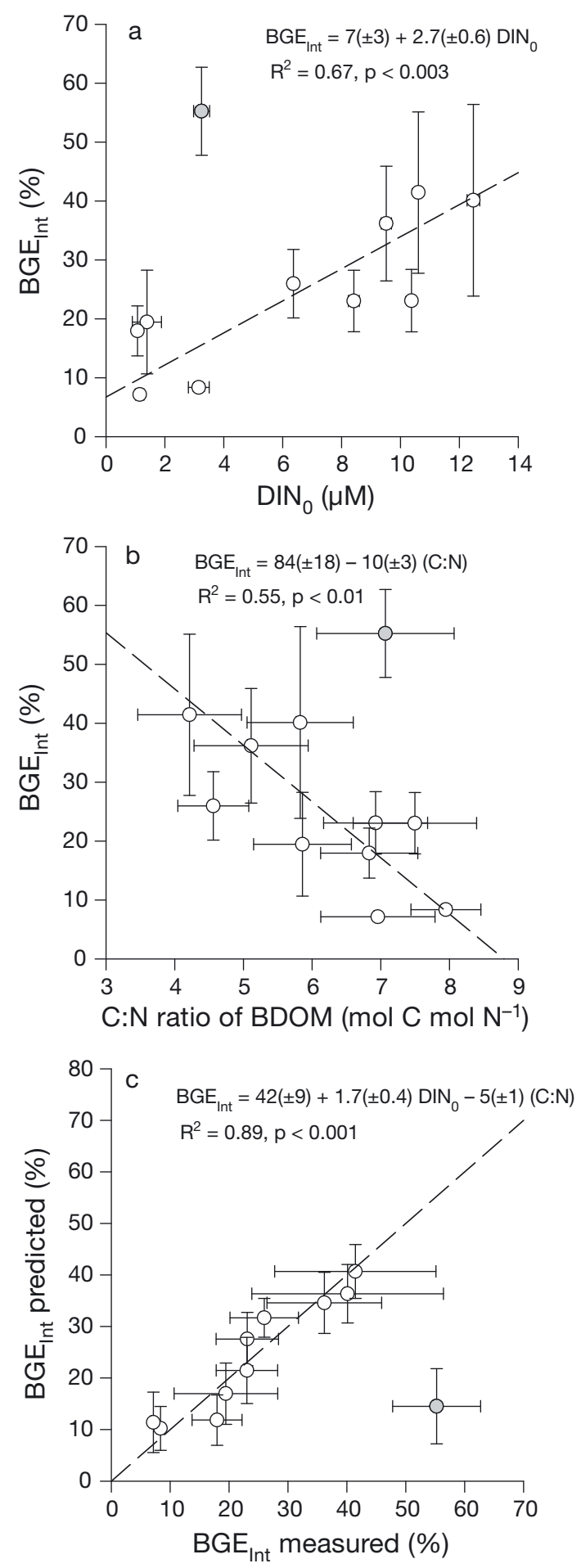

Fig. 2. Relationships between (a) initial dissolved inorganic nitrogen $\left(\mathrm{DIN}_{0}\right)$ concentration and (b) C:N ratio of bioavailable dissolved organic matter (BDOM) with $4 \mathrm{~d}$ integrated bacterial growth efficiency $\left(\mathrm{BGE}_{\mathrm{Int}}\right)$; and (c) relationship between measured and predicted $\mathrm{BGE}_{\text {Int }}$ from multiple linear regression with DIN and C:N ratio of BDOM. O: data point omitted from linear regression (10 Jul 2008). Dashed lines represent corresponding regression, with $\mathrm{R}^{2}=$ coefficient of determination, $\mathrm{p}=$ level of significance
$24 \mathrm{~h}$ almost $100 \%$ of the DAPI-stained cells were detected by fluorescence in situ hybridization with eubacteria probes, which strongly suggests that the percentage of nonliving cells in the dilution cultures was irrelevant. The respiration rates on a per-cell basis (Fig. 1) increased during the incubation, while $\mu$ declined (Table 2). This result suggests that respiration and $\mathrm{BCD}$ increase while $\mathrm{BP}$ and $\mathrm{BGE}$ decrease as the labile DOM fraction gets depleted. A similar decrease in the bacterial carbon conversion efficiency in the stationary phase of long-lasting (weeks) batch cultures was reported by Turley \& Lochte (1990). Therefore, as the incubations move towards more oligotrophic conditions, more carbon is used for energy production than for biomass production. Similar results have been obtained in natural systems where percentage BGE values decrease from eutrophic to oligotrophic waters (del Giorgio \& Cole 1998, Alonso-Sáez et al. 2007). Choosing between using instantaneous bacterial production and respiration estimates (short-term) or DOC degradation experiments (long-term) to calculate the BGE is associated with some potential problems. Short-term methods are limited essentially by the very distinct duration of the incubations for estimating bacterial production ( 1 to $2 \mathrm{~h}$ ) and respiration (usually $24 \mathrm{~h}$ ) and the need for several carbon conversion factors. The in vivo ETS method allowed us to reduce incubation time for respiration, thus solving the first problem. On the other hand, long-term methods rely on a single carbon conversion factor (bacterial carbon content), but changes in DOM quality as well as in bacterial phylogenetic composition over time may severely affect BGE estimates. Changes in the phylogenetic composition of the bacteria were measured during our incubations (Teira et al. 2009), but a potential influence of these changes on the BGE was not evident. The decrease observed between the initial and the final (after $4 \mathrm{~d}$ of incubation) instantaneous BGE estimates in our study indicate that longterm experiments could actually underestimate BGE. Nevertheless, the good agreement between our initial instantaneous $(28 \pm 13 \%)$ and integrated $(29 \pm$ $15 \%)$ BGE indicates that, in our study, the $4 \mathrm{~d}$ incubation did not severely underestimate BGE. Thus, the BGE estimated from changes in BB and DOC concentration over a few days seems to be a good approach, as it requires fewer carbon conversion factors than the short-term approach based on simultaneous BP and BR estimates. We do not know whether or how the conversion factors may have changed seasonally and during our incubations, but as our BGE estimates are similar to previously observed values, it suggests that our calculations are within the right range. 


\section{Bacterial carbon cycling over an annual cycle}

The energy transfer from heterotrophic bacteria to higher trophic levels is ultimately dependent on the BGE. The range (from $8 \pm 1$ to $55 \pm 11 \%$ ) and average $(27 \pm 15 \%)$ of the integrated BGE found in this study was comparable to values reported for marine systems ( 20\%; del Giorgio \& Cole 1998) and previous estimates for the NW Iberian upwelling system (from 12 to $20 \%$, Barbosa et al. 2001; from 2 to $27 \%$, Morán et al. 2002). The wide range of BGE showed that a variable BGE can be obtained at this site over an annual cycle and the average indicates that the bacterial community respired $72 \%$ of assimilated carbon, suggesting a low bacterial carbon transfer in this upwelling system.

Previous studies have indicated that BGE varies greatly depending on environmental factors such as nutrient availability (Rivkin \& Anderson 1997), DOM quality (Goldman et al. 1987, Lemée et al. 2002, Reinthaler \& Herndl 2005, Apple \& del Giorgio 2007) and temperature (Rivkin \& Legendre, 2001). Our data suggest that the BGE in the Ría de Vigo is partly controlled by inorganic nutrient availability and by the quality of the BDOM substrate (Fig. 2). The relationship suggests that the bacterial community requires energy (respiration) to take up DIN when the substrate has a high C:N ratio, resulting in lower BGE (Rivkin \& Anderson 1997, Kirchman 2000). Considering the values of the normalised regression slopes, $\beta_{1}$ $=0.637$ (for DIN) and $\beta_{2}=-0.491$ (for the $\mathrm{C}: \mathrm{N}$ ratio of BDOM), BGE depends more on DIN than on the quality of BDOM $\left(\beta_{2}{ }^{2} / \beta_{1}{ }^{2}=1.68\right)$. The importance of water temperature in regulating BGE cannot be determined in the present study as all incubations were conducted at the same constant temperature $\left(15^{\circ} \mathrm{C}\right)$. Nevertheless, some recent studies suggest that water temperature plays only a minor role in controlling BGE (Vázquez-Domínguez et al. 2007, Alonso-Sáez et al. 2008).

In summary, we have shown that the BCD and BGE changes over short time scales in laboratory incubations, and that the BCD and BGE in the upwelling area of the Ría de Vigo is controlled by the availability of carbon, inorganic nutrients and the composition of the BDOM pool. The study furthermore suggests that BGE depends more on inorganic nitrogen concentration than on the quality of DOM. Temporal and spatial differences in these variables may therefore have a large influence on the fate (new biomass vs. respiration) of organic carbon in the Ría de Vigo.

Acknowledgements. This study was funded by fellowships to C.L. from the early-stage training site ECOSUMMER (MESTCT-2004-020501) and the Carlsberg Foundation. We thank the captain, crew, and technicians of RV 'Mytilus' and the members of the Department of Oceanography of the Instituto de Investigacións Mariñas for their collaboration during the sampling program. Access to vessel time was provided by the RAFTING project (Impact of the mussel raft culture on the benthic-pelagic coupling in a Galician Ría, grant no. CTM2007-61983/MAR). E.T. was funded by a Juan de la Cierva MEC contract. We thank 2 anonymous reviewers for their valuable comments on the manuscript.

\section{LITERATURE CITED}

Alonso-Gutiérrez J, Lekunberri I, Teira E, Gasol JM, Figueras A, Novoa B (2009) Bacterioplankton composition of the coastal upwelling system of Ría de Vigo, NW Spain. FEMS Microbiol Ecol 70:161-173

Alonso-Sáez L, Gasol JM, Arístegui J, Vilas JC, Vaqué D, Duarte CM, Agustí S (2007) Large-scale variability in surface bacterial carbon demand and growth efficiency in the subtropical northeast Atlantic Ocean. Limnol Oceanogr 52:533-546

Alonso-Sáez L, Vázquez-Domínguez E, Cardelús C, Pinhassi $\mathrm{J}$ and others (2008) Factors controlling the year-round variability in carbon flux through bacteria in a coastal marine system. Ecosystems 11:397-409

Álvarez-Salgado XA, Gago J, Miguez BM, Pérez FF (2001) Net ecosystem production of dissolved organic carbon in a coastal upwelling system: the Ría de Vigo, Iberian margin of the North Atlantic. Limnol Oceanogr 46:135-147

Álvarez-Salgado XA, Borges AV, Figueiras FG, Chou L (2010) Iberian margin: the Rías. In: Liu KK, Atkinson L, Quiñones R, Talaue-McManus L (eds) Carbon and nutrient fluxes in continental margins: a global synthesis. Springer, Berlin, p 103-120

Apple JK, del Giorgio PA (2007) Organic substrate quality as the link between bacterioplankton carbon demand and growth efficiency in a temperate salt-marsh estuary. ISME J 1:729-742

Barbosa AB, Galvao HM, Mendes PA, Álvarez-Salgado XA, Figueiras FG, Joint I (2001) Short-term variability of heterotrophic bacterioplankton during upwelling off the NW Iberian margin. Prog Oceanogr 51:339-360

Carlson CA (2002) Production and removal processes. In: Hansell DA, Carlson CA (eds) Biogeochemistry of marine dissolved organic matter. Academic Press, New York, NY, p 59-90

Carlson CA, Bates NR, Ducklow HW, Hansell DA (1999) Estimation of bacterial respiration and growth efficiency in the Ross Sea, Antarctica. Aquat Microb Ecol 19:229-244

> Cermeño P, Marañón E, Pérez V, Serret P, Fernández E, Castro CG (2006) Phytoplankton size structure and primary production in a highly dynamic coastal ecosystem (Ría de Vigo, NW-Spain): seasonal and short-time scale variability. Estuar Coast Shelf Sci 67:251-266

Chavez FP, Toggweiler JR (1995) Physical estimates of global new production: the upwelling contribution. In: Summerhayes CP, Emeis KC, Angel MV, Smith RL, Zeitzschel B (eds) Upwelling in the ocean: modern processes and ancient records. Wiley, New York, NY, p 13-32

del Giorgio PA, Cole JJ (1998) Bacterial growth efficiency in natural aquatic systems. Annu Rev Ecol Syst 29:503-541

Fuhrman JA, Azam F (1980) Bacterioplankton secondary production estimates for coastal waters of British Columbia, Antarctica, and California. Appl Environ Microbiol 36: 1085-1095

> Fukuda R, Ogawa H, Nagata T, Koike I (1998) Direct determination of carbon and nitrogen contents of natural bacterial 
assemblages in marine environments. Appl Environ Microbiol 64:3352-3358

Gasol JM, Pinhassi J, Alonso-Sáez L, Ducklow H and others (2008) Towards a better understanding of microbial carbon flux in the sea. Aquat Microb Ecol 53:21-38

Gattuso JP, Frankignoulle M, Wollast R (1998) Carbon and carbonate metabolism in coastal aquatic ecosystems. Annu Rev Ecol Syst 29:405-433

Goldman JC, Caron DA, Dennet MR (1987) Regulation of gross growth efficiency and ammonium regeneration in bacteria by substrate C:N ratio. Limnol Oceanogr 32:1239-1252

Hansen HP, Koroleff F (1999) Determination of nutrients. In: Grasshoff K, Kermling K, Ehrhardt M (eds) Methods of seawater analysis. Wiley-VCH, Weinheim, p 159-226

Hedges JI (2002) Why dissolved organic matter? In: Hansell DA, Carlson CA (eds) Biogeochemistry of marine dissolved organic matter. Academic Press, London, p 1-33

Kirchman DL (ed) (2000). Uptake and regeneration of inorganic nutrients by marine heterotrophic bacteria. In: Microbial ecology of the oceans. Wiley, New York, NY, p 261-288

Lemée R, Rochelle-Newall E, Van Wambeke F, Pizay MD, Rinaldi P, Gattuso JP (2002) Seasonal variation of bacterial production, respiration and growth efficiency in the open NW Mediterranean Sea. Aquat Microb Ecol 29:227-237

Lønborg C, Álvarez-Salgado XA, Martínez-García S, Miller AEJ, Teira E (2010) Stoichiometry of dissolved organic matter and the kinetics of its microbial degradation in a coastal upwelling system. Aquat Microb Ecol 58:117-126

Martínez-García SE, Fernández E, Aranguren-Gassis M, Teira E (2009) In vivo electron transport system activity: a method to estimate respiration in natural marine microbial planktonic communities. Limnol Oceanogr Methods 7: 459-469

Morán XAG, Gasol JM, Pedrós-Alió C, Estrada M (2002) Partitioning of phytoplanktonic organic carbon production and bacterial production along a coastal-offshore gradient in the NE Atlantic during different hydrographic regimes. Aquat Microb Ecol 29:239-252

Nogueira E, Pérez FF, Ríos AF (1997) Seasonal patterns and long-term trends in an estuarine upwelling ecosystem (Ría de Vigo, NW Spain). Estuar Coast Shelf Sci 44:285-300

Reinthaler T, Herndl GJ (2005) Seasonal dynamics of bacter-

Editorial responsibility: Craig Carlson, Santa Barbara, California, USA ial growth efficiencies in relation to phytoplankton in the southern North Sea. Aquat Microb Ecol 39:7-16

Rivkin RB, Anderson MR (1997) Inorganic nutrient limitation of oceanic bacterioplankton. Limnol Oceanogr 42:730-740

> Rivkin RB, Legendre L (2001) Biogenic carbon cycling in the upper ocean: effects of microbial respiration. Science 291: 2398-2400

Sherry ND, Boyd PW, Sugimoto K, Harrison PJ (1999) Seasonal and spatial patterns of heterotrophic bacterial production, respiration, and biomass in the subarctic NE Pacific. Deep-Sea Res II 46:2557-2578

Sokal FF, Rohlf FJ (1995) Biometry: the principles and practice of statistics in biological research, 3rd edn. Freeman, New York, NY

Teira E, Abalde J, Álvarez-Ossorio MT, Bode A and others (2003) Plankton carbon budget in a coastal wind-driven upwelling station off A Coruña (NW Iberian Peninsula). Mar Ecol Prog Ser 265:31-43

Teira E, Martínez-García S, Lønborg C, Álvarez-Salgado XA (2009) Growth rates of different phylogenetic bacterioplankton groups in a coastal upwelling system. Environ Micro Reports 1:545-554

Tilstone GH, Figueiras FG, Fermín EG, Arbones B (1999) Significance of nanophytoplankton photosynthesis and primary production in a coastal upwelling system (Ría de Vigo, NW Spain). Mar Ecol Prog Ser 183:13-27

Turley CM, Lochte K (1990) Microbial response to the input of fresh detritus to the deep-sea bed. Palaeogeogr Palaeoclimatol Palaeoecol 89:3-23

Vázquez-Domínguez E, Vaque D, Gasol JM (2007) Ocean warming enhances respiration and carbon demand of coastal microbial plankton. Glob Change Biol 13: 1327-1334

> Walsh JJ (1991) Importance of continental margins in the marine biochemical cycling of carbon and nitrogen. Nature 350:53-55

Wollast R (1998) Evaluation and comparison of the global carbon cycle in the coastal zone and in the open ocean. In: Brink KH, Robinson AR (eds) The sea, Vol 10. John Wiley \& Sons, New York, NY, p 213-252

Yentsch CS, Menzel DW (1963) A method for the determination of phytoplankton chlorophyll and phaeophytin by fluorescence. Deep-Sea Res Oceanogr Abstr 10:221-231

Submitted: June 1, 2010; Accepted: January 20, 2011 Proofs received from author(s): March 29, 2011 